Received 24.03.2018

Reviewed $\quad 05.06 .2018$

Accepted 25.06.2018

A - study design

B - data collection

C - statistical analysis

D - data interpretation

$\mathbf{E}$ - manuscript preparation

F - literature search

\section{The use of the biological method for treating iron containing underground waters}

\footnotetext{
${ }^{1)}$ National University of Water and Environmental Engineering, Kiev, Ukraine; e-mail: o.m.kvartenko@nuwm.edu.ua; n.s.kovalchuk@nuwm.edu.ua

${ }^{2)}$ National Technical University of Ukraine "Igor Sikorsky" Kiev Polytechnic Institute, Kiev, Ukraine; e-mail: larisasabliy@ukr.net

${ }^{3)}$ Rivne State University of Humanities, Department of Ecology, Plastova str. 29a, 33028 Rivne, Ukraine; e-mail: lysycya@ukr.net
}

For citation: Kvartenko O., Sabliy L., Kovalchuk N., Lysytsya A. 2018. The use of the biological method for treating iron containing underground waters. Journal of Water and Land Development. No. 39 p. 77-82. DOI: 10.2478/jwld-2018-0061.

\begin{abstract}
The use of the biological method is promising for treating underground waters from iron compounds. Iron bacteria used in the process are widely spread in weak acidic and neutral underground waters containing iron ions (II), dissolved carbon dioxide and minimum concentrations of oxygen. The relevant direction of present-day biotechnology is the use of iron bacteria for treating underground waters. The goal of this research is to compare the efficiency of using the biological method for treating underground iron containing weak acidic and neutral waters under different conditions. As the testobjects, Gallionella and Lepthotrix iron bacteria were used. The sedimentation of bio-minerals was obtained from the washout waters of the biological deironing station. Calcium soda was used as an additional source of inorganic carbon for bacteria. As a result of the studies it is established that the use of the non-reagent method gives the possibility to achieve only $80 \%$ efficiency in removing iron compounds while the use of sodium carbonate results in increasing efficiency up to 93\%. To determine the contribution of biological purification of ground water from iron compounds, the bacteria were inhibited with the preparation of polyhexamethylene guanidine (PHMG) chloride. It was found that inhibition of Gallionella and Lepthotrix led to the reduction of $50 \%$ of the iron removal effect. The mechanism was developed of inhibiting the process of iron bacteria metabolism by PHMG (polyhexamethylene guanidine). The new technology of arranging a blockmodule station for treating underground waters is proposed.
\end{abstract}

Key words: biological method, iron bacteria, treatment stations, underground water

\section{INTRODUCTION}

In underground waters in many regions of the world, iron is present in different forms. In accordance with the data presented [CULLIMORE, MCCANN 1978], along with iron, in underground waters of 150 countries the iron bacteria of various types were discovered. In the researches [ASKERNIA et al. 2014], Gallionella, Lepthotrix bacteria were discovered in underground waters beyond the Arctic Circle, and in works [DU TOIT et al. 2014] their presence was described in the underground waters of South Africa. The iron bacteria may get into underground water carrying horizons as a result of drilling and maintenance of boreholes [EYKELBOSH 2013; SMITH 1995], as infiltration of surface waters from forest lakes and swamps [SAHA et al. 2016], and as potential migration from soils into underground horizons [HASSELBARTH, LUDEMANN 1972; HORN, RICHARDS 2010]. In most boreholes there is a sufficient amount of dissolved carbon dioxide and iron carbonate necessary for developing chemolithotrophic iron bacteria of Gallionella type. Under favorable conditions they may quickly propagate not only in boreholes themselves, but also in systems of water distribution in settlements. In this case the decrease of the carrying capacity of pipe lines 
takes place and the biological corrosion with further water pollution is possible [BEIMENG et al. 2015]. The scholars came to the conclusion that the optimal conditions for the development of iron bacteria are the values $\mathrm{pH}$ 6.0-8.0, $\mathrm{Fe}^{2+}>0.25 \mathrm{mg} \cdot \mathrm{dm}^{-3}$, dissolved oxygen in the range from 1.0 to $3.0 \mathrm{mg} \cdot \mathrm{dm}^{-3}$. Thus, it is possible to make a conclusion about widely spread presence of iron bacteria in weak acidic and neutral underground waters containing ions of iron (II), dissolved carbon dioxide and minimum concentrations of oxygen.

A wide range of technologies and methods for purifying groundwater can be used today. MARZEC et al. [2017] present results of researching water treatment from ions of iron, manganese, and also from colimorphic bacteria on filters loaded by silica carbonate. The main drawback of the suggested method is the necessity of correcting $\mathrm{pH}$ value of filtrate. The use of reagent method for acidifying the filtrate to the drinking water norms not only complicates the maintenance of technological equipment but also leads to making $1 \mathrm{~m}^{3}$ of treated water more expensive.

More perfect and reliable, in our opinion, is the method of simplified aeration with subsequent filtration on foam polystyrene filters [ORLOV et al. 2016]. However, it is to be pointed out that under the treatment of weak acidic waters with the low alkali reserve the described method is of low efficiency. In this case it is necessary to use the comprehensive method of bio-physical-chemical water treatment.

The actual direction of present-day biotechnology for water purification is the use of iron bacteria for treating underground waters in drinking water supply.

The aim of the study is the comparison of the efficiency of using the biological method for treating underground iron containing weak acidic and neutral waters under different conditions. The objectives are the following:

- to carry out the qualitative and quantitative analysis of bio-minerals matrix in the space between the pores with the contact loading of the bioreactor;

- to compare the efficiency of using schemes of the biological deironing in weak acidic and neutral waters;

- to determine the effect of "polyhexamethylene guanidine" (PHMG) on the rate of the iron bacteria activity, and to study the mechanism of this process;

- to carry out the approbation of the suggested method at the operating station of water treatment.

The research was conducted in stages in accordance with the identified points.

\section{MATERIAL AND METHODS OF RESEARCH}

The sedimentation of bio-minerals was obtained from the washout waters of the biological deironing station. At the first stage, the roentgen-spectral analysis of the composition of sedimentation and matrix structure study were carried out with the help of the scanning microscope FEI Quanta.

At the second stage, the comparative researches were performed to determine the efficiency of using iron bacteria in various conditions. The pilot experimental installation is composed of the coming out water container with the volume of $2000 \mathrm{~cm}^{3}$, a reaction flask of $500 \mathrm{~cm}^{3}$ volume, a Kamovskiy pump, a flask with the changeable paper filter and a ceramic filter, a magnetic mixer MM-5, a system of rubber hoses, scheme is presented in Figure 1. Into the coming out water container there was added the calculated amount of $0.1 \mathrm{n}$ hydrochloric solution and iron (II) sulphate.

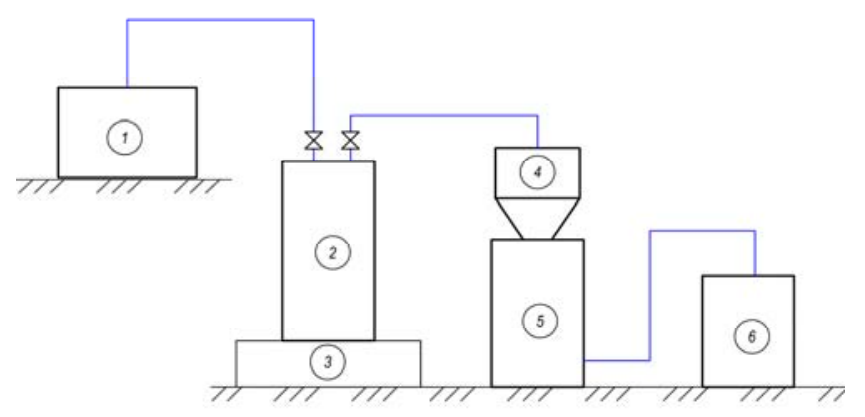

Fig. 1. Scheme of experimental installation; $1=$ coming out imitation solution container; 2 = reaction flask; $3=$ magnetic mixer; $4=$ hermetic ceramic filter; $5=$ flask of filtrate collection; $6=$ Kamovskiy pump; source: own study

The use of imitation solutions with high concentrations of iron ions and small content of dissolved oxygen permits to investigate the kinetics of the process of biological deironing by decreasing to the minimum the impact of dissolved oxygen in the capacity of oxidizer. Oxygen is used to support aerobic conditions necessary for developing iron bacteria. The concentration of oxygen was $1.0-2.0 \mathrm{mg} \cdot \mathrm{dm}^{-3}$. The parameters of the quality of imitation solutions are given in Table 1.

Table 1. Quality parameters of the water under research

\begin{tabular}{|c|c|c|c|c|}
\hline \multirow{2}{*}{$\begin{array}{c}\text { No of experi- } \\
\text { mental samples }\end{array}$} & \multicolumn{5}{|c|}{ Parameter of solution quality } \\
\cline { 2 - 5 } & $\mathrm{pH}$ & $\begin{array}{c}\mathrm{Fe}^{2+} \\
\mathrm{mg} \cdot \mathrm{dm}^{-3}\end{array}$ & $\begin{array}{c}\mathrm{Na}_{2} \mathrm{CO}_{3} \\
\mathrm{mg} \cdot \mathrm{dm}^{-3}\end{array}$ & $\begin{array}{c}\text { PHMG } \\
\text { vol. \% }\end{array}$ \\
\hline \multicolumn{5}{|c|}{ Weak acid imitation aqueous solutions } \\
\hline 1 & 6.3 & 37.0 & - & - \\
\hline 2 & 6.3 & 38.0 & 80.0 & - \\
\hline 3 & 6.3 & 38.0 & - & $1 \cdot 10^{-2} \%$ \\
\hline 4 & 5.8 & 41.0 & 40.0 & $2 \cdot 10^{-6} \%$ \\
\hline \multicolumn{7}{|c|}{ Neutral imitation aqueous solutions } \\
\hline 5 & 7.0 & 39.0 & 40.0 & $1 \cdot 10^{-2} \%$ \\
\hline 6 & 7.0 & 37.0 & - & - \\
\hline
\end{tabular}

Explanation: $\mathrm{PHMG}=$ polyhexamethylene guanidine.

Source: own results.

At the third stage, the testing of the suggested method of the biochemical oxidation under working conditions was conducted. The construction of the water treatment station included the aeration device, a contact column of $450 \mathrm{~mm}$ diameter and $4000 \mathrm{~mm}$ high and several filters with the diameter of $720 \mathrm{~mm}$ and $3200 \mathrm{~mm}$ high. In the capacity of loading filters, the foam self-attenuating polystyrene was used, with fractions grain size of $0.8-2.0 \mathrm{~mm}$. The thickness of filtering layer being $1500 \mathrm{~mm}$. In the capacity of test objects, the Gallionella and Lepthotrix iron bacteria were used. 


\section{RESULTS AND DISCUSSION}

The research conducted at the first stage permitted to carry out the qualitative and quantitative evaluation of the matrix structure of iron bacteria in the space between the pores with the contact loading of the bioreactor (Fig. 2).
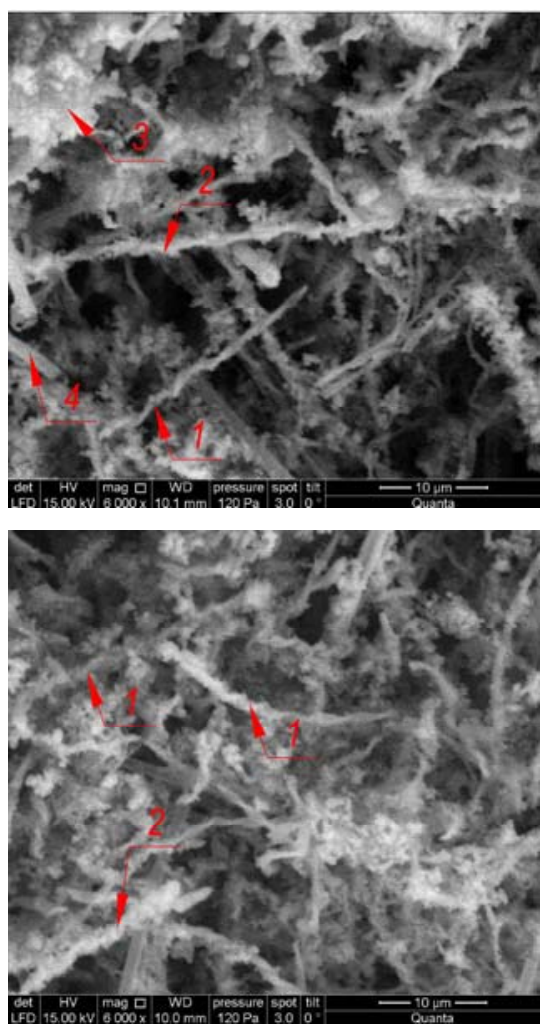

Fig. 2. Microphotographs of matrix structures of biominerals obtained with the help of scanning electronic microscope FEI

Quanta; 1 = spiral-like covers of Gallionella ferruginea; $2=$ crystalline precipitate of iron oxyhydrate on bacterial covers of Gallionella ferruguinea; 3 = agglomerates of matrix structure; 4 = tubular structures of Lepthothrix; 6000x; source: own study

Figure 2 shows the inner structure of the porous matrix consisting of random mixture of biominerals, covers of various kinds of iron bacteria both free and incrusted with the crystal-like sediment of lepidocrokite and iron hydrate. As is seen from the presented materials, the domination of Gallionella iron bacteria in the sediment was observed. The presented matrices (Fig. 2) were formed in the intraporous space of the bioreactor included into the construction of the station for underground water treatment. The quantitative results of the spectral analysis of the sediment obtained at the expense of diffraction of X-rays, the scanning electronic microscopy (SEM) are given in Table 2.

From the survey of the data of spectral analysis it is seen that the composition of matrix includes iron, precipitated by a bacterial method, carbon, nitrogen and phosphorus which testifies to its organic constituent.

At the second stage of the research, the comparative analysis of the changing dynamics in time of $\mathrm{Fe}^{2+}$ concentration in the suspended layer of sediment from biominerals matrices in weak acidic and neutral waters was
Table 2. Elemental composition of sediment from intra-porous space of bioreactor at underground water treatment station

\begin{tabular}{|c|c|c|c|c|c|c|c|c|}
\hline \multirow{2}{*}{$\begin{array}{c}\text { Cover of } \\
\text { Gallionella } \\
\text { bacteria }\end{array}$} & \multicolumn{8}{|c|}{ Composition of elements (\%) } \\
\hline & $\mathrm{C}$ & $\mathrm{N}$ & $\mathrm{O}$ & $\mathrm{Si}$ & $\mathrm{P}$ & $\mathrm{S}$ & $\mathrm{Ca}$ & $\mathrm{Fe}$ \\
\hline In weight & 7.95 & 1.58 & 37.00 & 4.24 & 0.07 & 0.25 & 0.91 & 48.00 \\
\hline Atomic & 15.51 & 2.64 & 54.23 & 3.54 & 0.05 & 010 & 047 & 23.37 \\
\hline
\end{tabular}

Source: own results, quantitative result of the spectral analysis (SEM).

conducted. The research was carried out under the conditions of: a) non-reagent processing (Fig. 3, curves 1, 6); b) the use of the solution of soda ash (Fig. 3, curve 2); c) using PHMG solution (Fig. 3, curve 3); d) complex processing of the researched water by solutions of soda ash and PHMG (Fig. 3, curves 4, 5).

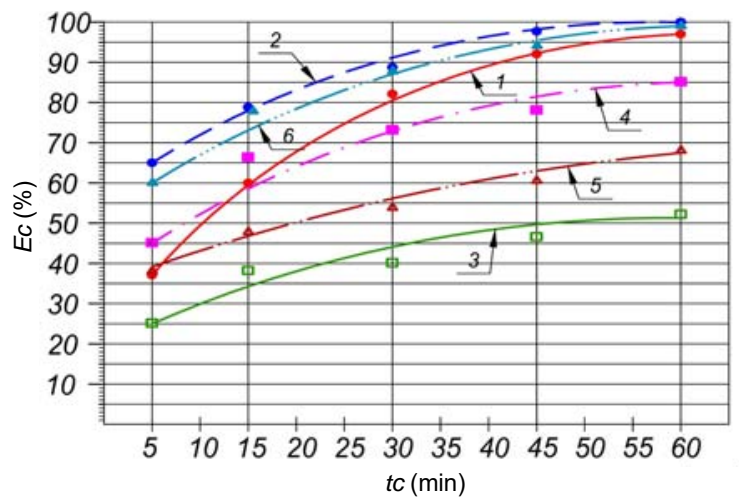

Fig. 3. The kinetics $(E c)$ of the concentration ratio of $\mathrm{Fe}^{2+}$ ions in suspended sediment from matrix biomineral; water quality parameters of graphs $1-6$ are presented in the Table 1; source: own study

According to the results of the performed comparative studies it is possible to draw conclusions as below.

- When using a non-reagent scheme during the first 30 min while processing neutral waters, the efficiency of treatment is higher than in the treatment of weak acidic waters (Fig. 3, curve 1,6).

- When using the solution of soda ash, in a weak acidic medium, the activation of biochemical processes with the increased effect of treatment during the period of 5 to $30 \mathrm{~min}$ is observed (Fig. 3, curve 2), which by 1.7 times exceeds the efficiency by a non-reagent scheme (Fig. 3, curve 1). The mechanism of activation of the process of oxidizing iron ions by Gallionella iron bacteria is presented in paper by KVARTENKO et al. [2017].

- To determine the contribution of the share of biological treatment of underground waters from iron compounds into the total process of deironing, we had conducted a pilot study with the addition of PHMG solution into a reaction flask. In using the inhibitor with concentration $1 \cdot 10^{-2} \%$ (vol. \%), in a weak medium (Fig. 3, curve 3 ) the efficiency of removing iron during the first 30 min constituted $40 \%$, and further the curved line came out on the plateau.

- With the combined use of soda ash and PHMG solutions, depending on the concentration of a poly-cation, there were observed two variants of developing the 
treatment process. With the concentration of a polycation $1 \cdot 10^{-2} \%$ (Fig. 3, curve 5) the change of iron ions concentrations was constant in time. While using low concentrations of PHMG $2 \cdot 10^{-6} \%$ (Fig. 3, curve 4 ), the efficiency of treatment increased to $85 \%$.

\section{THE MECHANISM OF INHIBITING THE PROCESS OF IRON BACTERIA METABOLISM BY THE POLYHEXAMETHYLENEGUANIDINE}

By the results of the researches, the PHMG polycation is operating toxically beginning with initial concentrations in solution $10^{-3} \%$ and higher [LYSYTSYA 2017]. The studies testify that molecules of this poly-cation are repeatedly combining with phospholipids of cytoplasmic membrane (CPM) and under the bacteria-static concentrations change its ionic permeability, electric potential, the operation of transmembrane fermenting systems, and under the bactericides ones they cause perturbation of lipid bilayer, destruction of CPM and the death of a cell [CARMONA-Ribeiro, DE Melo CARRASCO 2013; CHOI et al. 2017]. In our opinion, the process of blocking the normal operation of iron bacterium cell takes place by such mechanism. At first, large polymeric molecules of the preparation are adsorbed on big sectors of the cell shell surface, blocking in this way the operation of the poly-cellular ferment restucian and the transfer of electrons to the breathing chain, and also the operation of the flowing pump and the transport of metabolites outside. As a result, there occur irreversible structural damages at the level of cytoplasmic membrane with the subsequent violation in the operation of other cellular systems.
Under the action of PHMG on Leptothrix iron bacteria, besides the described earlier mechanism, there may be the blocking of the fermentative system by it which is responsible for the work of a catalase. When there is inhibition of these enzymes in the cell, the accumulation of substantial concentrations of hydrogen peroxide will take place, which during the blocking of ports for removing the metabolism products outside the boundaries of the cellular membrane will result in the cells lysis. If the concentrations of the PHMG are less than $10^{-5} \%$, then the stimulating effect is observed from the action of PHMG, the proliferation of cells is being speeded up. Thus, the bactericidal concentration of PHMG $\left(1 \cdot 10^{-2} \%\right)$ inhibits the processes of biochemical oxidation of iron ions by iron bacteria.

At the third stage, the results of the laboratory researches were tested at the operating station of deironing with the productivity of $5 \mathrm{~m}^{3} \cdot \mathrm{h}^{-1}$, scheme is presented in Figure 4.

The parameters of the quality of the coming out water are the following: $\mathrm{Fe}^{2+} 4.6 \mathrm{mg} \cdot \mathrm{dm}^{-3}$, alkalinity (A) $1.6-1.7$ $\mathrm{mmol} \cdot \mathrm{dm}^{-3}$, permanganate oxidability (PO) 2.85-3.55 $\mathrm{mg} \mathrm{O}_{2} \cdot \mathrm{dm}^{-3}$, pH 6.45-6.55. The block-scheme of the operating station is presented in Fig. 4. The coming out water is supplied by pipeline (1) via the aeration assemblage (6) to the circular partition-like mixer (4), mixing before that with the solution of soda ash (8). The soda ash solution is supplied by the dosage pump (15) from the tank (16). Further on by a transferring pipeline (7) the water is admitted to the lower part of the contact column where the processes of the preliminary oxidation of polluted substances are taking place. From the contact column the water is admitted to the lower part of foam-polystyrene filters through the sys-

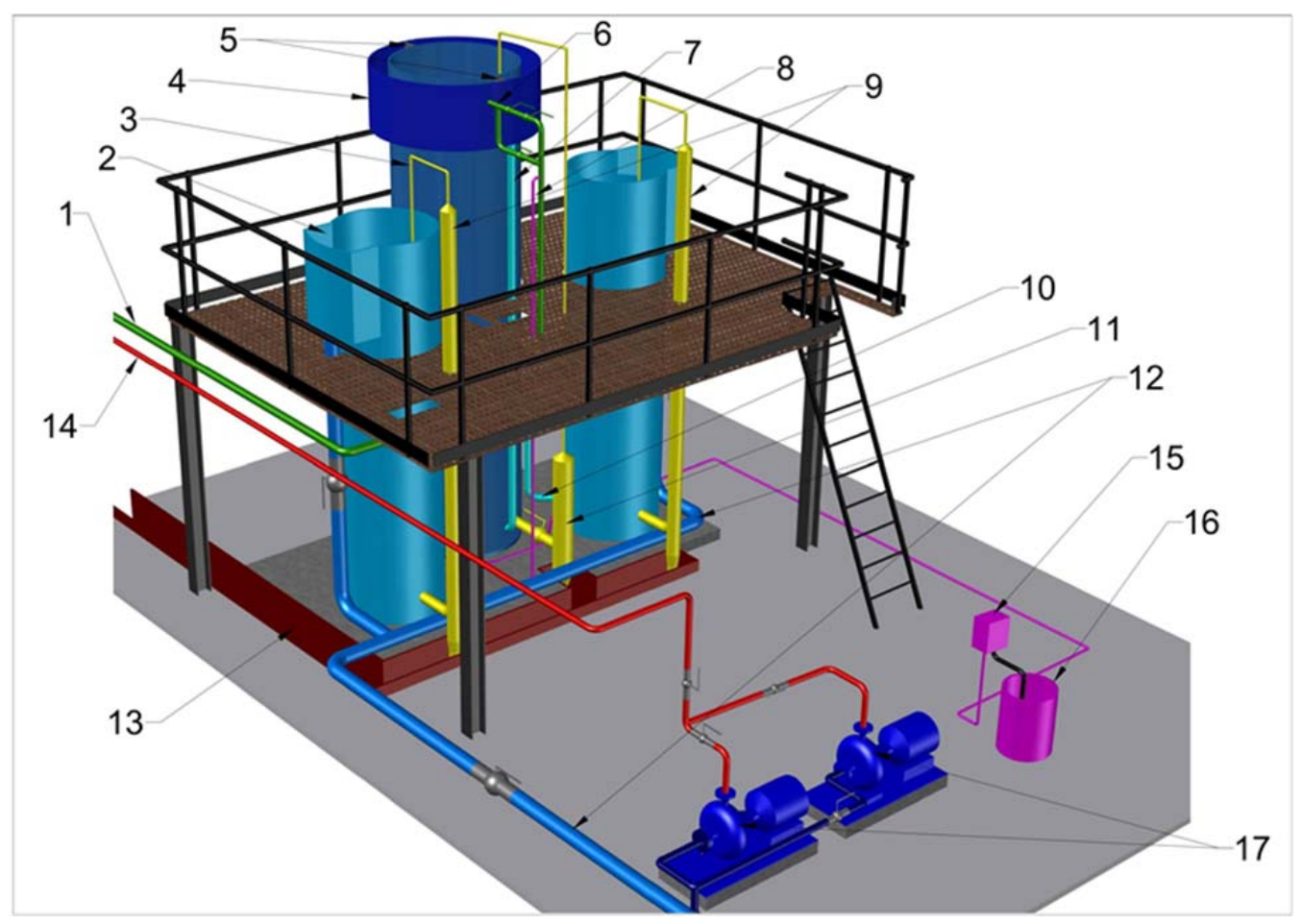

Fig. 4. Scheme of block-module station of underground water treatment; $1=$ pipeline $; 2=$ pockets $3=$ vacuum break pipe, $4=$ circular partition-like mixer, $5=$ partitions, $6=$ aeration assemblage, $7=$ transferring pipeline, $8=$ solution of soda ash, $9,11=$ system of hydro-robots, $10=$ system of pipelines, $12=$ technological pipelines, $13=$ pipeline for filtrate removal, $14=$ pipeline, $15=$ dosage pump, $16=\operatorname{tank}, 17=$ pumps; source: own results 
tem of pipelines (10). Filtering is performed in the rising flow with the velocity of $2.5-3.0 \mathrm{~m} \cdot \mathrm{h}^{-1}$. Clean water is collected in the above-filter space and via the pockets (2) and technological pipelines (12) is directed to clean water reservoir (CWR). The washing out of the filtration loading is carried out with the intensity of $12.0 \mathrm{dm}^{3} \cdot \mathrm{s}^{-1} \cdot \mathrm{m}^{-2}$, during $80 \mathrm{~s}$ under the hydro-automatic conditions with the help of the system of hydro-robots $(9,11)$. Water from CWR with the help of pumps (17) by a pipeline (14) is directed to the consumer.

The results of the comparative studies of the operation of the station are given in Figure 5. The slight efficiency of iron compounds oxidizing process, in the first case (Fig. 5, curve 1) is explained by low bicarbonate alkalinity of the coming out water, the presence of aggressive carbon dioxide (up to $50 \mathrm{mg} \cdot \mathrm{dm}^{-3}$ ) and dissolved humic acids. The use of the additional source of carbon in the form of the solution of soda ash (Fig. 5, curve 2) permitted to increase the value of bicarbonate alkalinity of the system to 2.0 $2.2 \mathrm{mmol} \cdot \mathrm{dm}^{-3}$ and to activate the activity of Gallionella iron bacteria.

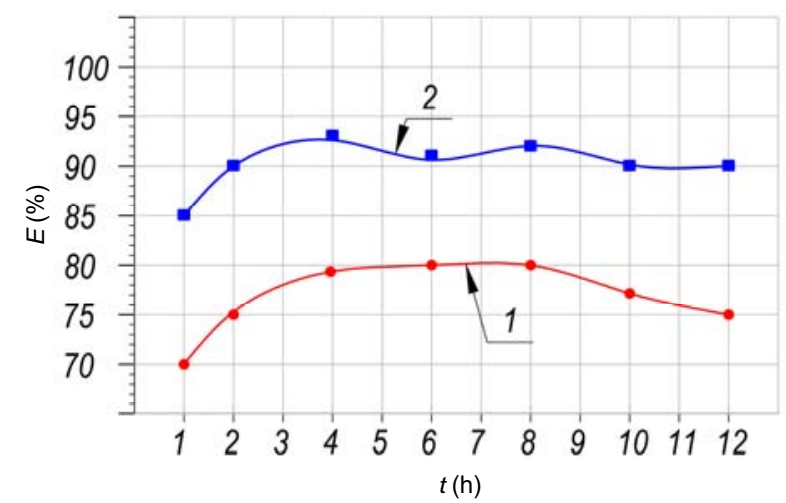

Fig. 5. Change in the efficiency $(E)$ of water purification throughout the filter cycle: $1=$ without using additional carbon source; 2 = using the solution of soda ash; $t=$ time; source: own study

\section{CONCLUSIONS}

As a result of the researches it was determined that matrix structures are composed of non-ordered mixture of biominerals, covers of various kinds of iron bacteria with the dominant presence of Gallionella. The quantitative results of spectral analysis of a bacterium cover showed that the composition of matrix structures included iron, carbon, nitrogen, and phosphorus, which testifies to its organic constituent. The comparative studies carried out concerning the removal of $\mathrm{Fe}^{2+}$ ions by iron bacteria consortiums in weak acidic and neutral media, showed the efficiency of biological treatment under the conditions with non-substantial (up to $2.0 \mathrm{mg} \cdot \mathrm{dm}^{-3}$ ) oxygen content resulting in the increased efficiency while using the additional source of non-organic carbon. It was established that using concentrations of polyhexamethyleneguanidine (PHMG) $1 \cdot 10^{-2} \%$, the decrease of up to $50 \%$ of the total effect of deironing was observed. The mechanism was proposed for blocking the normal life activity of iron bacteria by PHMG. The comparative research was carried out at the operating station of water treatment as a result of which it is established that the use of the non-reagent method renders the possibility of removing up to $80 \%$ iron compounds, while the use of soda ash increases the efficiency of treatment process up to $93 \%$.

\section{REFERENCES}

Askernia A.A., Sorokina A.IU., Dubinina G.A. 2014. Mikrobiologicheskie aspekty processov obezzhelezivaniya i demanganacii prirodnykh podzemnykh vod [Microbiological aspects of natural underground water deironing and demanganation] [online]. Water Supply and Sanitary Technique. Iss. 12 p. 14-21. [Access 21.02.2018]. Available at: http://vstmag.ru/ru/archives-all/2014/2014-12

Beimeng Q.I., CHONGweI C., YiXING YU. 2015. Effects of iron bacteria on cast iron pipe corrosion and water quality in water distribution systems [online]. International Journal of Electrochemical Science. Vol. 10 p. 545-558. [Access 21.02.2018]. Available at: http://www.electrochemsci.org/ papers/vol11/110100545.pdf

Carmona-Ribeiro A.M., De Melo Carrasco L.D. 2013. Cationic antimicrobial polymers and their assemblies. International Journal of Molecular Sciences. Vol. 14 p. 9906-9946. DOI 10.3390/ijms14059906.

Choi H., KIM K.J., LeE D.G. 2017. Antifungal activity of the cationic antimicrobial polymer-polyhexamethylene guanidine hydrochloride and its mode of action. Fungal Biology. Vol. 121. Iss. 1 p. 53-60. DOI 10.1016/j.funbio.2016.09.001.

Cullimore D.R., MCCANN A.E. 1978. The identification, cultivation and control of iron bacteria in ground water [online]. Aquatic Microbiology. Eds. F.A. Skinner, J.M. Shewan. Academic Press pp. 32. [Access 21.02.2018]. Available at: https://www.dbi.ca/Books/PDFs/Water-Paper.PDF

Du Toit G., Blignaut H., Theunissen B., Briggs J. 2014. Biological filtration for sustainable treatment of groundwater with high iron content - A case study [online]. Water SA. [Access 21.02.2018]. Available at: http://www.awa.asn.au/ documents $/ 079 \% 20 \% 20$ GDuToit.pdf

EyKelbosh A.J. 2013. Review of guidelines for shock chlorination in private wells [online]. Vancouver. NCCEH pp. 11. [Access 21.02.2018]. Available at: http://www.ncceh.ca/ sites/default/files/Shock_Chlorination_Wells_Nov_2013.pdf

HASSELBARTH U., LUDEMANN D. 1972. Biological incrustation of wells due to mass development of iron and manganese bacteria. Water Treatment and Examination. Vol. 21 p. 20-29.

HorN B., RicharDS G. 2010. Use of degradable, non-oxidizing biocides and biodispersants for the maintenance of capacity in nutrient injection wells [online]. Proceedings of the Annual International Conference on Soils, Sediments, Water and Energy. Vol. 13. Article 5. [Access 21.02.2018]. Available at: http://scholarworks.umass.edu/soilsproceedings/vol13/iss1/5

KVARTENKo O., GryUK I., SABLIY L. 2017. Model of biomineralization of ferrum compounds by Gallionella cells immobilized on contact loading of bioreactor [online]. Energy Engineering and Control Systems. Vol. 3. No. 2 p. 51-56. [Access 21.02.2018]. Available at: https://doi.org/10.23939/jeecs 2017.02.051

LYSYTSYA A.V. 2017. Research on the impact of polyhexamethyleneguanidine on the plant component of biocenoses. Biosystems Diversity. Vol. 25. Iss. 2 p. 89-95. DOI 10.15421/ 011713.

Marzec M., PieńKo A., GizińsKa-Górna M., PytKa A., JóźWiakowski K., SosnowsKa B., KamińSKA A., Listosz A. 2017. The use of carbonate-silica rock (opoka) to remove iron, manganese and indicator bacteria from groundwater. 
Journal of Water and Land Development. No. 34 p. 197-204. DOI 10.1515/jwld-2017-0054.

MAshat B.H. 2016. Polyhexamethylene biguanide hydrochloride: features and applications. British Journal of Environmental Sciences. Vol. 4. Iss. 1 p. 49-55.

ORLOV V., MARTYNOV S., KUNYTSKIY S. 2016. Energy saving in water treatment technologies with polystyrene foam filters. Journal of Water and Land Development. No. 31 p. 119-122. DOI 10.1515/jwld-2016-0042.
Saha U., Sonon L., Ayers E., PARKS D., Lessl J.Th. 2016. Iron (manganese) and sulfur bacteria in your well water [online]. Bulletin. No. 1457. The University of Georgia and Fort Valley State University, the U.S. Department of Agriculture and Counties of the State Cooperating pp. 11. [Access 21.02.2018]. Available at: https://secure.caes.uga.edu/ extension/publications/files/pdf/B\%201457_1.pdf

SMITH S.A. 1995. Monitoring and remediation wells: Problem prevention, maintenance, and rehabilitation. Boca Raton. CRC Press. ISBN 9780873715621 - CAT\# L562 pp. 208.

\section{Oleksandr KVARTENKO, Larysa SABLIY, Nataliya KOVALCHUK, Andriy LYSYTSYA}

Wykorzystanie metody biologicznej do oczyszczania wód podziemnych zawierających żelazo

\section{STRESZCZENIE}

Metoda biologiczna stwarza obiecującą możliwość oczyszczania wód podziemnych ze związków żelaza. Bakterie żelazowe używane w tym procesie są szeroko rozpowszechnione w słabo kwaśnych i obojętnych wodach podziemnych zawierających jony żelaza (II), rozpuszczony ditlenek węgla i minimalne stężenie tlenu. Współczesne kierunki w biotechnologii zmierzają do użytkowania bakterii żelazowych w procesie uzdatniania wód podziemnych. Celem przedstawionych badań było porównanie w różnych warunkach wydajności metody biologicznej stosowanej do uzdatniania słabo kwaśnych i obojętnych wód podziemnych zawierających żelazo. Obiektem badań były bakterie żelazowe Gallionella i Lepthotrix. Biominerały sedymentowały z wód płuczących pochodzących ze stacji odżelaziania wody. Jako dodatkowe źródło nieorganicznego węgla dla bakterii użyto węglan sodu. W wyniku przeprowadzonych badań ustalono, że wykorzystanie metody bez dodatku odczynnika umożliwia osiągnięcie 80-procentowej wydajności usuwania związków żelaza; dodanie węglanu sodu zwiększa tę wydajność do 93\%. W celu określenia udziału biologicznego oczyszczania wód gruntowych ze związków żelaza zahamowano aktywność bakterii za pomocą chlorowodorku poliheksametylenoguanidyny (PHMG). Stwierdzono, że zahamowanie aktywności Gallionella i Lepthotrix zredukowało efekt usuwania żelaza o 50\%. Opracowano mechanizm hamowania metabolizmu bakterii przez PHMG. Zaproponowano nową technologię blokowo-modułową dla stacji uzdatniania wód podziemnych.

Slowa kluczowe: bakterie żelazowe, metoda biologiczna, stacja uzdatniania wody, wody podziemne 